\title{
Rapid Resolution of Multiple Liver Abscesses in a Chronic Granulomatous Disease Patient with Granulocyte Transfusions
}

\author{
Çoklu Karaciğer Apsesi Olan Bir Kronik Granülomatöz Hastasının \\ Granülosit Transfüzyonu ile Hızlı Tedavisi
}

\author{
Azize PInar METBULUT ${ }^{1}$, Ayse METIN¹, Omer GUNES², Gulsum Iclal BAYHAN², Guzin CINEL ${ }^{3}$, \\ Gulsah BAYRAM ILIKAN ${ }^{4}$, Abdurrahman KARA ${ }^{5}$
}

\author{
${ }^{1}$ Ankara City Hospital, Children's Hospital, Pediatric Immunology and Allergy Clinic, Ankara, Turkey \\ ${ }^{2}$ Ankara City Hospital, Children's Hospital, Pediatric Infectious Diseases Clinic, Ankara, Turkey \\ ${ }^{3}$ Ankara City Hospital, Children's Hospital, Pediatric Chest Diseases Clinic, Ankara, Turkey \\ ${ }^{4}$ Ankara City Hospital, Clinic of Radiology, Ankara, Turkey \\ ${ }^{5}$ Ankara City Hospital, Children's Hospital, Pediatric Hematology Clinic, Ankara, Turkey
}

\begin{abstract}
Chronic granulomatous disease (CGD) is a genetically heterogeneous primary immune deficiency of phagocyte function characterized by recurrent, life-threatening bacterial and fungal infections that lead to granuloma formation. Early diagnosis is possible by the awareness of the clinician about early infectious clues of the disease. Aggressive treatment of infectious complications is very important in CGD patients and subsequently antimicrobial (antibiotic and antifungal) and immunomodulatory (interferon-gamma) prophylaxis until hematopoietic stem cell transplantation. Despite improved mortality, morbidities due to complications associated with CGD remain significant. One of these is a hepatic abscess in CGD patients which is seen in more than one-quarter of patients and also very refractory and frequently requires multiple surgeries with frequent morbidities. Therefore, the most optimal and beneficial treatments are still being investigated in the world. We present a 3 y old CGD patient with multiple liver abscesses due to S.aureus and Aspergillus spp who treated by several percutaneous liver-directed interventional radiological treatment along with granulocyte transfusions.
\end{abstract}

Key Words: Child, Granulomatous disease, Liver abscess

\section{Öz}

Kronik granülomatöz hastalık (CGD), tekrarlayan, yaşamı tehdit eden bakteri ve mantar enfeksiyonları ile karakterize olan, granülom oluşumuna yol açan genetik olarak heterojen bir primer immün yetmezlik olan fagosit fonksiyon yetersizliğidir. Erken teşhis, klinisyenin hastalığın erken enfeksiyon ipuçları konusunda bilinçlenmesi ile mümkündür. CGD hastalarında Enfeksiyöz komplikasyonların agresif tedavisi çok önemlidir ve hematopoietik kök hücre nakline kadar antimikrobiyal (antibiyotik ve antifungal) ve immünomodülatör (interferon-gama) profilaksileri de çok önemlidir. Mortalitenin azalmasına rağmen, CGD ile ilișkili komplikasyonlara bağlı morbiditeler önemini korumaktadır. Bunlardan biri, CGD hastasında, hastaların dörtte birinden fazlasında görülen ve aynı zamanda çok dirençli ve sıklıkla sık morbiditeli birden fazla ameliyat gerektiren karaciğer apsesidir. Bu nedenle dünyada halen en uygun ve faydalı tedaviler araștırılmaktadır. Granülosit transfüzyonları ile birlikte perkütan karaciğere yönelik girişimsel radyolojik tedavi ile tedavi edilen S.aureus ve Aspergillus spp'ye bağlı çoklu karaciğer apsesi olan 3 yaşında bir CGD hastasını sunuyoruz.

Anahtar Kelimeler: Çocuk, Granulomatöz hastalık, Karaciğer absesi

(i)

METBULUT AP

METIN A

GUNES O

GUNES O

BAYHAN

CINEL G

BAYRAM ILIKAN G

KARA A
Conflict of Interest /Çıkar Çatışması: On behalf of all authors, the corresponding author states that there is no conflict of interest.

Financial Disclosure / Finansal Destek: The authors declared that this case has received no financial support.

Confirmation / Onay: The written consent was received from the patient who was presented in this study.

How to cite / Atıf Yazım Sekli : Metbulut AP, Metin A, Gunes O, Bayhan Gl, Cinel G, Bayram llikhan G, Kara A. Rapid Resolution of Multiple Liver Abscesses in A Chronic Granulomatous Disease Patient with Granulocyte Transfusions. Turkish J Pediatr Dis 2022;16: 70-74.

Additional information / Ek Bilgi: Thanks to Dr. Yavuz Koker from Erciyes University for dihidro-rhodamine 123 test.
Correspondence Address / Yazışma Adresi :

Azize Pınar METBULUT

Ankara City Hospital, Children's Hospital,

Pediatric Immunology and Allergy Clinic, Ankara, Turkey

E-posta: pinar298@yahoo.com
Received / Geliş tarihi : 14.01.2021 Accepted / Kabul Tarihi : 20.04.2021

Online published 23.09.2021

Elektronik yayın tarihi

DOI:10.12956/tchd.858827 


\section{INTRODUCTION}

Chronic granulomatous disease (CGD) is caused by mutations leading to defects in subunits of the phagocyte NADPHoxidase (gp91phox in X-inked; p22phox, p47phox, p67phox, and p40 in autosomal recessive-CGD) (1). The NADPHoxidase-myeloperoxidase system generates microbicidal, reactive oxygen species required for host defense and control of inflammation (1).

CGD affects 1:200 000 live births (2). X-linked-CGD accounts for approximately two-thirds of patients in Europe but in countries where consanguineous marriages are prevalent AR-CGD patients predominate (3-7). Symptoms comprise invasive infections and chronic autoinflammatory diseases (complications) leading to aggressive medical interventions, long hospitalizations, impaired quality of life, and increased morbidity/mortality (3-6) (Table I).

Infections typically affect organs in contact with the outside world like skin, gastrointestinal tract, and lungs as well as lymph nodes that drain these organs. Because of adjacent tissue and hematogeneous spread of the infection other organs can be affected especially the liver, bones, kidneys, and brain. Pathogens responsible for these clinical presentations are catalase-positive microorganisms as seen in Table I.

The use of life-long antibacterial prophylaxis with trimethoprimsulfamethoxazole is recommended. Pulmonary Aspergillus infections are the leading cause of mortality. Anti-fungal prophylaxis mainly with itraconazole can reduce the incidence of fungal infections (1-3). One of the most serious errors in the management of CGD patients is the failure to treat potentially serious infections early and to continue therapy long enough to eradicate them.

Although neutrophil absolute numbers are normal in CGD patients, it can be considered functional neutropenia because the killing function is impaired. Granulocyte transfusions have been used to treat infections in neutropenic patients for nearly 30 years (8-10) (Table II). The data from recent systematic reviews suggest that properly collected and promptly infused granulocytes are active against bacterial and fungal infections in the patient. The most important question is in which patients the administration of granulocytes will be necessary. Prominent evidence suggests that granulocyte transfusions should be used in selected cases, as a final measure to control an infection that is expected to be refractory to optimal antimicrobial treatment. In this regard, CGD patients who do not have their neutrophil response to the infection are good candidates for granulocyte transfusions (Table II).

It was planned to present our CGD patient with multiple liver abscesses to emphasize the characteristics of the use of granulocyte transfusion, which is a rare treatment method, the infection in CGD patients is usually due to resistant microorganisms, which are not common in the society, and its proven benefit in organ abscesses and rapidly spreading skin infections.

Table I: Infections, chronic complications, and organisms responsible in CGD patients in order of frequency.

\begin{tabular}{l|ll}
\hline \multicolumn{1}{c}{ INFECTIONS } & \multicolumn{1}{c}{ CHRONIC COMPLICATIONS } & \multicolumn{1}{c}{ INFECTING ORGANISMS } \\
\hline Pneumonia & Lymphadenopathy & Staphylococcus aureus \\
\hline Lymphadenitis & Hypergammaglobulinemia & Escherichia coli \\
\hline Cutaneous infection-impetigo & Hepatosplenomegaly & Aspergillus species \\
\hline Hepatic-perihepatic abscess & splenomegaly & Salmonella species \\
\hline Osteomyelitis & Anemia of chronic infection & Klebsiella species \\
\hline Septicemia & Underweight & Burkholderia cepacia \\
\hline Otitis media & Short stature & Staphylococcus epidermidis \\
\hline Conjunctivitis & Chronic diarrhea(Crohn-like) & Serratia marcescens \\
\hline Enteric infections & Gingivitis & Enterobacter species \\
\hline Urinary tract infections & Dermatitis & Streptococcus species \\
\hline Sinusitis & Chorioretinitis & Proteus species \\
\hline Renal-perinephric abscess & Hydronephrosis & Candida species \\
\hline Brain abscess & Ulcerative stomatitis & Nocardia species \\
\hline Pericarditis & Pulmonary fibrosis & Bacillus Calmette-Guérin \\
\hline Meningitis & Esophagitis & Mycobacterium species \\
\hline & Gastric antral narrowing & Chromobacterim violaceum \\
\hline & Granulomatous ileocolitis & Candida glabrata \\
\hline
\end{tabular}


Table II. Indications of granulocyte transfusions.

\begin{tabular}{l} 
Minimal criteria: \\
\hline Absolute neutrophil count $<500 / \mathrm{mm}^{3}$ \\
Evidence of bacterial or fungal infection \\
Unresponsiveness to antimicrobial treatment for at least 48 hours \\
Cancer patients with severe neutropenia and fatal infections \\
Chemotherapy or HSCT-induced neutropenia \\
Aplastic Anemia \\
Congenital disorders of neutrophil function (Leucocyte Adhesion \\
Deficiencies, Congenital Severe Neutropenia syndromes, \\
Chronic Granulomatous Disease)
\end{tabular}

\section{CASE REPORT}

A 3 y old male patient from a Syrian immigrant family, admitted first when he was $18 \mathrm{mo}$ old, to the Republic of Turkey, Ministry of Health, Ankara City Hospital, Children's Hospital, Emergency Department with a complaint of scrotal swelling. On admission, there was a left apical cervical, $1.5 \times 1.5 \mathrm{~cm}$ diameter lymphadenopathy, submandibular pigmented scars left due to previous suppurative lymphadenitis, hepatomegaly $1 \mathrm{~cm}$ below the costal margin, palpable left inguinal lymphadenopathy, multiple micro epididymal, and scrotal abscess. His weight was $10 \mathrm{~kg}$. The patient consulted the Pediatric Immunology Unit for primary immunodeficiency diseases and especially for congenital defects of phagocyte number and functional defects due to the skin and soft tissue infections of the patient. Parents were first-degree relatives (cousins). The patient was the $1^{\text {st }}$ child of the family, and $2^{\text {nd }}$ child was $7 \mathrm{mo}$ old and healthy. There was a perianal abscess in the newborn period in his history. He was hospitalized and the biopsy of the cervical lymph node was reported as necrotizing granulomatous inflammation by the pathologist. The patient was evaluated with the immunological screening tests as seen in Table III. Nitroblue tetrazolium test showed the killing defect of the neutrophils of the patient and the Dihidro-rhodamine 123 test showed that the patient's probable mutant NADPH-oxidase component is p67 phox protein according to the stimulation index found. Mutation analysis results are pending for the precise diagnosis. After antimicrobial treatment, he was given the drug reports and prescriptions of prophylactic TMP-SMX $5 \mathrm{mg} / \mathrm{kg} / \mathrm{d}$, 3 days $/$ week, per oral.; itraconazole $5 \mathrm{mg} / \mathrm{kg} / \mathrm{d}$, every day, per oral., and interferongamma (Imukin $®$-1b 100mcg flacon) 3 days/week, sc. and called for Pediatric Immunology outpatient clinic controls. Since the patient had a routine BCG vaccine, no history of BCGitis, a PPD test was applied. Since the result was $18 \mathrm{~mm}$, chest radiography and CT were taken due to the possibility of active TB infection. It was normal; prophylactic Isoniazid and Rifampicin treatments (both $10 \mathrm{mg} / \mathrm{kg} / \mathrm{d}$ dose) were started for latent TB. The family belonged to a low socio-cultural level and could bring the child 12 months later for the new complaints of the child. They stated that they could not give the TMP-SMX, itraconazole continuously and regularly, except prophylactic TB drugs. Since the family was a Sirian immigrant, we contacted Sirian Social Aid Organisations in Turkey but Imukin could not be provided. His current complaints were $>38^{\circ} \mathrm{C}$ fever of 5 days, abdominal pain, severe weakness, and pallor. The patient was hospitalized again in 2020 October. Physical examination revealed oral moniliasis, abdominal distention, bilateral suppurative cervical lymphadenitis with $3 \times 3 \mathrm{~cm}$ diameter. Laboratuary tests were given in Table III. Abdominal USG and abdominal MRI revealed multiple (nearly 8-9) subcapsular and scattered abscesses the biggest ones sized 42x48, 28x20, and $34 \times 27 \mathrm{~mm}$ diameter at the right lobe of the liver. There were another abscess sized $23 \times 17$ adjacent to the upper part of the right kidney with an undetectable capsular border. There were also multiple reactive mesentery lymphadenopathies and minimal free liquid collection. Computed tomography of the thorax showed no appearance in favor of pulmonary TB and Aspergillus pneumonia when compared with previous $\mathrm{MR}$, but $18 \mathrm{~mm}$ right pleural effusion. Cranial MRI was normal. Treatment began with meropenem, vancomycin, teicoplanin, amikacin, and caspofungin. IVIG was added as a single dose to support the treatment in a $0.5 \mathrm{~g} / \mathrm{kg} / \mathrm{dose}$. Subcapsular hepatic abscesses drained percutaneously. Despite these treatments, fever, blood, and abscess culture yields of S.capitis in the blood; Aspergillus spp. and Staphylococcus spp in the hepatic abscess respectively, and the high number of the abscesses led us to decide to give granulocyte transfusion (GTX) to the patient. After the 14th day, vancomycin and caspofungin stopped and voriconazole was begun. After GTXs and multiple (3 times) interventional abscess drainages until they solidify, he remained afebrile, imaging showed improvement of all the abscesses, and the return of the erythrocyte sedimentation rate to its normal baseline $(<20 \mathrm{~mm} / \mathrm{h})$, the patient could be discharged after 1.5 months of antibiotic and antifungal treatment, returning to the routine CGD prophylaxis and increasing the awareness of the family about CGD, the decision was made to prepare for bone marrow transplantation. The patient was also discharged with continuing voriconazole treatment.

\section{DISCUSSION}

Recurrent cutaneous abscesses and lymphadenitis represent the earliest and common types of infection in CGD as seen in our patient. Impetigo, froncules frequently in the perianal area due to feces contamination as well as recurrent perirectal abscess are seen (Table I). These require prolonged courses of oral and topical antibiotics to clear and once formed can persist for years despite aggressive antimicrobial treatment.

Hepatic and perihepatic abscesses were also quite common in CGD as seen in our patient, mostly caused by the hematogenous spread of S.aureus in patients who are incompatible with 
Table III: Immunological screening tests and other laboratory parameters of the patient on the two admissions.

\begin{tabular}{|c|c|c|}
\hline & First admission & Second admission \\
\hline $\begin{array}{l}\text { CBC } \\
\text { WBC } \\
\text { ANC } \\
\text { ALC } \\
\text { Plt } \\
\text { Hb/Hct } \\
\text { Eosinophil(\%/Absolute) }\end{array}$ & $\begin{array}{c}3930 \\
2000 \\
1100 \\
728000 \\
12.5 / 36 \\
12(471)\end{array}$ & $\begin{array}{c}18770 \\
12770 \\
4830 \\
774000 \\
9 / 27 \\
1(200)\end{array}$ \\
\hline $\begin{array}{l}\text { Serum immunoglobulins(mg/dl) } \\
\text { lgG } \\
\lg M \\
\lg A \\
\lg E(U / m l)\end{array}$ & $\begin{array}{c}1550 \\
250 \\
155 \\
500\end{array}$ & \\
\hline $\begin{array}{l}\text { Lymphocyte subpopulations } \\
\text { CD3+ Total Tcell(\%/Absolute) } \\
\text { CD4+Helper T cell (\%/Absolute) } \\
\text { CD8+ supressor T cell(\%/Absolute) } \\
\text { CD19+ B cell(\%/Absolute) } \\
\text { CD16+56 NK cell (\%) }\end{array}$ & $\begin{array}{c}65 \\
37 \\
25 \\
26 \\
9\end{array}$ & \\
\hline Nitroblue Tetrazolium Test (NBT) & $0 \%$ & \\
\hline Dihidro-rhodamine 123 test & $\begin{array}{l}\text { P67phox mutation is possible } \\
\text { according to the pattern. }\end{array}$ & \\
\hline $\begin{array}{l}\text { Complement (mg/dl) } \\
\text { C3 } \\
\text { C4 }\end{array}$ & $\begin{array}{c}100 \\
30\end{array}$ & \\
\hline CRP/Sedimentation on admission & $3 \mathrm{mg} / \mathrm{dl} ; 75 \mathrm{~mm} / \mathrm{h}$ & $12,7 \mathrm{mg} / \mathrm{dl} ; 100 \mathrm{~mm} / \mathrm{h}$ \\
\hline The isolated pathogen in culture & S. aureus & S. aureus+ Aspergillus spp \\
\hline Liver/ Renal function tests & Normal limits & Normal limits \\
\hline Coagulation tests(PT, PTT, D-dimer, Fibrinogen, Ferritin) & Normal & High \\
\hline
\end{tabular}

the prophylactic treatment. Spontaneous rupture can be seen, again as seen in our patient. Liver function tests are often normal. Hepatic abscesses in CGD are phenotypically distinct from the pyogenic liver abscesses associated with other conditions. They present as septate masses surrounded by a thick pseudocapsule containing amorphous cell debris in it which is difficult to drain. The resolution requires open surgical drainage or excision of the lesion (other surgical procedures may also be necessary such as liver resection, segmentectomy, or lobectomy); percutaneous interventional radiological procedures, and high dose corticosteroid use together with several months of targetted parenteral antibiotics $(8,9)$. It is hypothesized that steroid-induced reduction of systemic inflammation reduces immune cell infiltration in the liver microenvironment and so reduces the need for procedural intervention and prevents complications. Corticosteroids (prednisone or methylprednisolone) as immunomodulatory management are used in a median dose of $1 \mathrm{mg} / \mathrm{kg} / \mathrm{day}$ and subsequently tapered over a median of 5 months $(8,9)$.

In recent years the prognosis of these organ abscesses has dramatically improved with the use of GTX. In cases of severe fungal and bacterial infections that fail to respond to medical and surgical approaches, GTX is necessary to shorten the healing process.

We have experience with GTX in our hospital in severe necrotizing pneumonia, Aspergillus pneumonia, cerebral and cerebellum abscesses, osteomyelitis, and liver abscess in at least ten X- and AR-CGD patients to date. We observed its effectiveness in curing infections in CGD patients. We gave GTX also to this patient once in three days, from 4 unrelated donors with only one transfusion reaction of fever in the last infusion. Due to this reaction, the last GTX had to be cut in the half. He received high-dose granulocyte per body weight (Weight: 10 $\mathrm{kg}$ ) since each granulocyte products contained $2.9 \times 1010,1.4$ x1010, $1.2 \times 1010$ and 1.5 x1010 neutrophils respectively. We did not prefer steroid use in this patient because the patient's cultures obtained from drainage procedures were positive for Aspergillus spp and the danger of spread could be increased with steroids.

The Apheresis Unit of our hospital has a well-established granulocyte donor and patient preparation protocol for donor selection, viral screening, time and amount of G-CSF and dexamethasone doses are given to the donor, apheresis procedure (time to obtain the largest amount of granulocytes), 
premedications given to the patient, and infusion rates (transfusing the product within 8 hours). We did not see any severe adverse reaction after GTX in our CGD patients, while some patients develop hypoxemia and pulmonary infiltrates after GTX with a frequency of $10 \%$ in some CGD patient trials $(10,11)$.

There is another issue to be considered in CGD. Special attention must be given to CGD patients' transfusions, whether they be GTX, erythrocytes, or platelets $(1,2)$. Some X-CGD patients have McLeod syndrome. Since the Kx protein is absent and other Kell antigens are weakly expressed on erythrocytes of X-CGD patients, they will become quickly sensitized to the Kell antigens if they are not transfused with $\mathrm{Kx}$-negative McLeod blood products. If the molecular genetic basis of the CGD patient is not known erythrocyte antigen phenotyping should be studied before the first transfusion of the CGD patient because it is not possible to prevent red blood cell contamination during the apheresis procedure. Our patient's Kell blood group phenotyping was negative.

However, GTX often leads to alloimmunization which may significantly impair the likelihood of successfull hematopoietic stem cell transplantation later on. Thus because of the increasing desire for HSCT in CGD, we reserve GTX for severe complications and use unrelated donors only in our patients. HLA and neutrophil alloimmunization in CGD patients who received frequent GTX in a study was 70\% (14/18) (12).

To conclude, hepatic abscesses occurring in patients with CGD represent a clinically significant and life-threatening complication. GTX's may be life-saving and time-saving for the patient since evidence reveals that these lesions respond quickly to viable granulocytes to overcome the immunodeficient immune system of the CGD patients.

\section{REFERENCES}

1. Segal $B H$,Leto $T L$, Gallin JI, malech HI, holland SM. genetic, biochemical, and clinical features of chronic granulomatous disease. Medicine 2000; 79:170-200.

2. Ahlin A, Fasth A. Chronic granulomatous disease- conventional treatment vs. hematopoietic stem cell transplantation: an update. Curr Opin Hematol 2015; 22:41-5.

3. Winkelstein JA, Marino MC, Johnston RB Jr, Boyle J, Curnutte $\mathrm{J}$, Gallin Jl, et al. Chronic granulomatous disease. Report on a national registry of 368 patients. Medicine. 2000; 79:155-69.

4. T Turul-Özgür, G Türkkani-Asal, I Tezcan, MY Köker, A Metin, L Yel, et al. Clinical features of chronic granulomatous disease: a series of 26 patients from a single center. Turk J Pediatr 2010;52: 576-81.

5. Köker MY, Camcıoğlu Y, van Leeuwen K, Kılıç SŞ, Barlan I, Yılmaz $\mathrm{M}$, et al. Clinical, functional, and genetic characterization of chronic granulomatous disease in 89 Turkish patients. J Allergy Clin Immunol 2013;132;1156-63.

6. Köker MY, Sanal O, De Boer M, Tezcan I, Metin A, Ersoy F, Roos D. Mutations of chronic granulomatous disease in Turkish families. Eur J Clin Invest 2007; 37: 589-95.

7. MY Köker, Ö Sanal, M De Boer, I Tezcan, A Metin, C Tan, F Ersoy, D Roos. Skewing of X-chromosome inactivation in three generations of carriers with $\mathrm{X}$-linked chronic granulomatous disease within one family. Eur J Clin Invest 2006; 36: 257-64.

8. Lublin M, Bartlett DL, Danforth DN, Kauffman H, Gallin JI,Malech $\mathrm{HL}$ et al. Hepatic abscess in patient with chronic granulomatous disease. Annals of Surgery 2002;235:383-91.

9. Straughan DM, McLoughlin KC, Mullinax JE, Marciano BE, Freeman AF, Anderson $\mathrm{VL}$ et al. The changing paradigm of management of liver abscesses in chronic granulomatous disease. Clin Infect Dis 2018;66:1427-34.

10. Price TH, Boeckh M, Harrison RW, McCullough J, Ness $P M$, Strauss RG, et al .Efficacy of transfusion with granulocytes from G-CSF/dexamethasone treated donors in neutropenic patients with infection. Blood 2015;126: 2153-61.

11. Gea-Banacloche. Granulocyte transfusions: A concise review for practitioners. Cytotherapy 2017;19: 1256-69.

12. Stroncek DF, Leonard K, Eiber G, Malech HL, Gallin JI, Leitman SF. Alloimmunization after granulocyte transfusions. Transfusion 1996;36:1009-15. 